\title{
Victimization and Fear of Crime in Rural Tanzania
}

Professor Dr. Frank Neubacher

Institute of Criminology

University of Cologne

Köln, Germany

Professor Dr. Anja Faße

Chair of Environmental Policy and Resource Economics

Weihenstephan University of Applied Sciences,

TUM Campus Straubing for Biotechnology and Sustainability

Straubing, Germany

Dr. Nicole Bögelein

Institute of Criminology

University of Cologne

Köln, Germany

Prof. Dr. Ulrike Grote

Institute for Environmental Economics and World Trade

Leibniz University of Hanover

Hannover, Germany

Corresponding author: Professor Dr. Frank Neubacher; f.neubacher@uni-koeln.de; 00492214704281

\begin{abstract}
The article presents findings from a crime victims survey which was conducted as a household survey in six Tanzanian villages in the summer of 2016. The results reveal that the villagers have been victimized at a high rate, mostly in relation to the theft of livestock or crops. While 37 percent of the households reported having been victimized during the last 12 months, 71 percent of all incidents were related to theft. Repeated victimization is not a rare case. Fear of theft is widespread and needs to be understood in the context of food security. Furthermore, the article pictures how victims deal with crime events in terms of reporting behavior, conflict mediation, and prevention measures.
\end{abstract}

Keywords: developing countries, rural area, crime victims survey, theft, farm crime, opportunities, reporting behavior, fear of crime 


\section{Introduction}

Criminology is, by its very nature, an international and transdisciplinary science. Nonetheless, most findings are concerned with the developed, especially the Western, world. There are many reasons for this: on the one hand the strong position of Anglo-American criminology, which focuses on the USA and Europe, and on the other hand, the various difficulties of conducting field research in developing countries. As a result, criminality and life situations in developing countries, especially in rural areas, are yet a most desirable research field, but vastly understudied (Neubacher \& Grote, 2016; Grote \& Neubacher, 2016). Respective research would not only cover gaps as far as concrete crime phenomena are concerned, it could also include the testing of general principles, e.g. crime theories. This research is also of interest to related disciplines (e.g. geography, development research). Its further political relevance can be defined by the key words - development, cooperation, and migration. Hence, a prudent development policy should not hide crime phenomena because crime adversely affects rural people and communities in various ways. For example it acts as an enhancer of social inequality or as a barrier to investments because it threatens the livelihoods and can make migration seem attractive.

The purpose of the present paper is to show and analyze for the first time empirical data from a research project conducted in Tanzania. In this article, the background of the project as well as the methodological approach will be explained before the results about the expressed fears, victimization rates, and the reactions to victimization will be presented. As far as the state of research is concerned, we will confine ourselves here to emphasize the most important findings. Statements on the scope and structure of registered crime on the basis of official statistics are not useful because it is assumed that most of the crimes committed are not reported by the victims. This is mainly due to a widespread fear of the police and little confidence in their investigatory effectiveness. Moreover, the distances to the nearest police station are usually very large, and traditionally, trust is higher towards a local authority, e.g. a village elder. Accordingly, a large dark figure is to be assumed and therefore statements on everyday crime are best possible on the basis of direct surveys. The results of the International Crime Victims Survey (ICVS), which has been carried out repeatedly since 1989 (Zvekic \& Alvazzi Del Frate, 1995; Alvazzi Del Frate 1998; van Dijk 2008; van Kesteren, van Dijk \& Mayhew, 2014), suggest that people in developing countries are more often affected by crime than people in developed countries. In general, farms and land used for agricultural purposes are suitable for theft (Bunei, Rono \& Chessa 2013; Ceccato 2016; Grote \& Neubacher 2016). 


\section{The Research Project}

\section{Background and survey instrument}

The Institute for Environmental Economics and World Trade of the Leibniz Universität Hannover has been conducting research in developing countries, especially in South-East Asia and sub-Saharan Africa for years. Lately, the focus was on the question of how rural households living close to the poverty line react to external shocks caused by crop failures, droughts, floods, or the like. In this context, the idea arose that crime may also be an external shock that requires adaptation. This is all the more true, as poor households can be put in a precarious food insecure situation by the theft of field crops or cattle (Chiwona-Karltun, Lemenih, Tolera, Berisso \& Karltun, 2017). In order to assess the impact of criminality and its consequences for households, a separate questionnaire section titled "Crime" was developed together with the Institute of Criminology of the University of Cologne, and integrated into the survey of the villagers.

The general questionnaire gave a detailed account of the socio-economic characteristics of households, the nature of agricultural activities, other sources of income, expenditure for and consumption of foodstuffs, and possible shocks and related coping strategies. The section on crime at the end of the questionnaire consisted of a total of 36 questions. It comprised three parts, of which the first - even before any relationship to crime had been established - openly raised interviewees' concerns and fears with regard to the further development of the village.

The second part of the survey focused mainly on victimization experiences in the past 12 months. It included similar questions and was similarly structured as the ICVS. However, numerous new questions were developed, in particular on the different theft experiences, on corruption and the circumstances of the offense. The main focus was on questions of everyday crime, in particular various forms of theft, including (accomplished and attempted) burglary, robbery, fraud, embezzlement, bodily injury, damage to property, and corruption experiences (related to education, health, and police / criminal justice). This part was preceded by an introduction which stressed that the reported victimization - experienced by the interviewees or other household members - must have occurred during the past 12 months and must have been caused by someone unrelated to the household. Sexual offenses as well as domestic violence were excluded, in order not to burden the questioning situation. If a question was affirmed, additional questions were asked: about the frequency of the respective victimization (multiple victimization) during the past 12 months, about time and place of the victimization, about the severity of the offense, and the damage done.

The third part of the questionnaire addressed possible reactions to victimization. This part was mainly about the reporting behavior and the corresponding motivations, but also about the trust in the police, village leaders, or other authorities. Finally, three case vignettes were designed each which described the circumstances of an offense (insult, theft, bodily injury, see annex). The interviewees were then asked to assess the severity of these three different legal infringements. 


\section{Study area, samples and methodological approach}

The study was carried out in two rural regions of Tanzania: Morogoro and Dodoma. In both areas (see Figure 1), small farmers are predominant and the food situation is insecure. In the subhumid Morogoro region maize, vegetables, rice and sesame are mainly cultivated, and there is little livestock farming. The supply of food for the population varies and is not guaranteed throughout. In the predominantly semiarid region of Dodoma, where a long dry phase and very rainy months alternate, millet (sorghum and other types of millet), peanuts and sunflowers dominate - with pronounced livestock farming. The supply situation is difficult on the whole and there are regular periods of food shortages. The districts of Kilosa (Morogoro) and Chamwino (Dodoma) were selected as study regions because they represent about 70 to 80 percent of the land-based management systems in Tanzania with respect to the agroecological conditions (Graef et al., 2014).

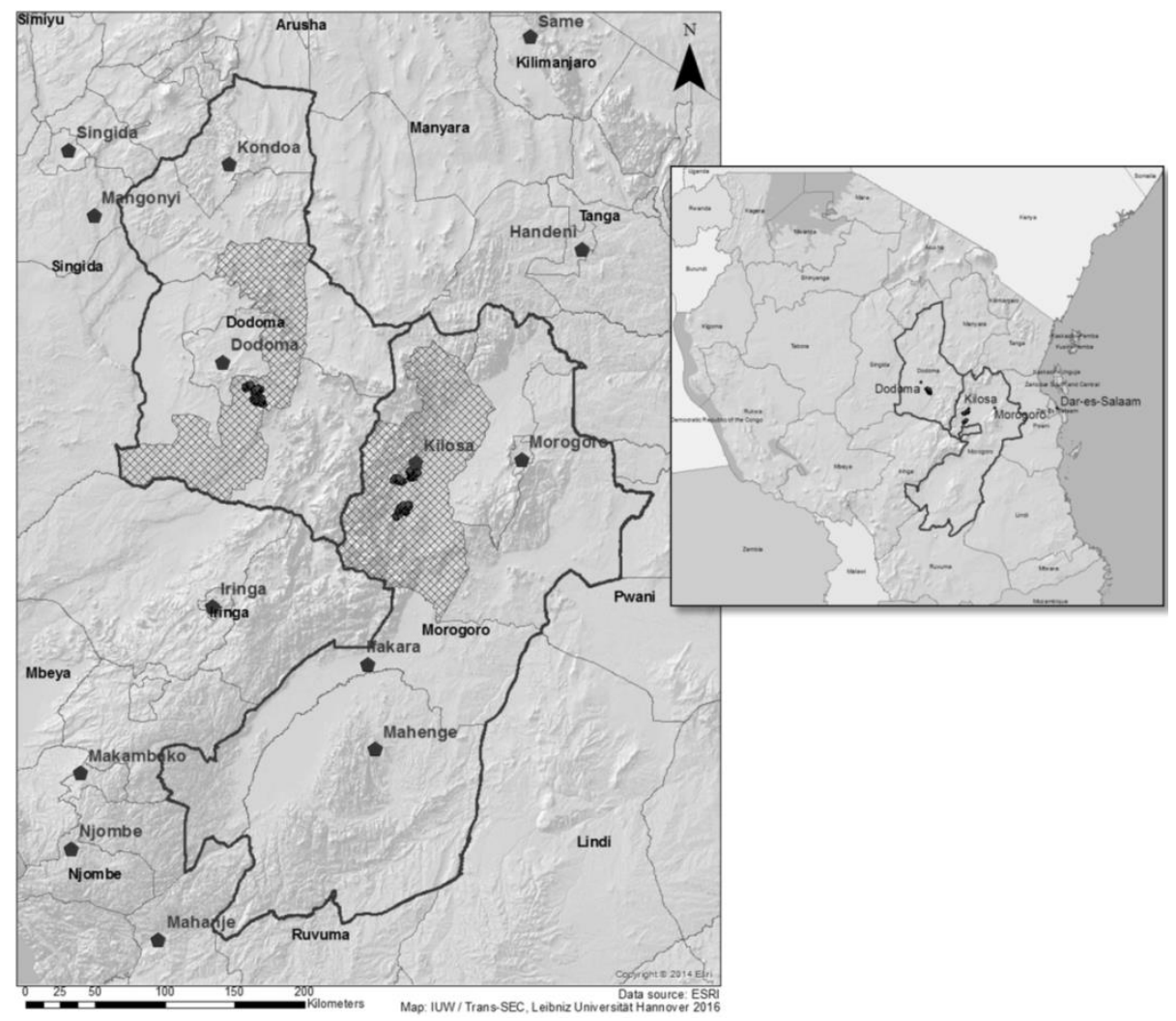

Figure 1: Study region in Tanzania (Source: Trans-SEC Survey, 2014)

In the district of Kilosa (Morogoro), the survey was conducted in the villages of Changarawe, Nyali and Ilakala, and in the district of Chamwino (Dodoma), the villages of Ilolo, Ndebwe and Idifu. The sampling criteria were as follows: (1) different market access; (2) similar climatic conditions; (3) rainfed agriculture; (4) present livestock farming; and (5) similar village size (800-1,500 households). 
The survey of the 900 households started in June, 2016 and lasted about six weeks. In each of the six villages, 150 households were randomly selected on the basis of household lists, taking into account the size of the village. The survey was carried out as a computer-assisted personal interview in cooperation with the Agricultural Faculty of the University of Morogoro, whose staff had been intensively trained for a week before the survey. The interviews lasted an average of three to four hours each. The questions were read to the households in Kiswahili; the answers were entered in English language. The respective wording of the questions is cited in the text. Soon after the interviews, the results were checked on the completeness of the responses and regular plausibility checks ensured a high quality to the data.

\section{Results}

\section{Fears with regard to the future development of the village}

As described, the "Crime Section" of the questionnaire was introduced with an open question of general fears and fears regarding the development of the village, without the interviewers having indicated any crime phenomena beforehand. This clarification appears necessary in order to adequately classify the answers (Table 1). The interviewees thus had the possibility of instigating three possible answers from respondents, and then to rank them ("rank 1", "rank 2", "rank 3"). The open question was worded as follows: "We would now like to learn about the life in your village. Is there anything you are afraid of when you think of the future of your village? Please let us know what you are most afraid of." Because of the numerous notions regarding crime phenomena, responses were further subdivided into the categories "Theft" and "Other Crimes" and "Killing".

Of the 820 households surveyed, 363 households (44.3\%) named three things of which they were afraid. Two hundred and three households (24.8\%) gave two responses and 195 households $(23.8 \%)$ named one fear. Fifty-nine households (7.2\%) reported no fears.

In order to be able to evaluate the various responses ranging from economic and health problems - such as "black magic", "land robbery", and thefts - the individual responses were allocated to different fear categories for the analysis. "Land robbery" refers to the taking of land by individuals, such as by local elites. Details of the classification of all crimes are provided in Appendix A.

As can be seen from the fears stated first by the interviewees, fear of theft dominates (Table 1); not less than 38.4 percent of the respondents mentioned theft first. General conflicts were mentioned less frequently. These are mostly about land use rights, which is why it seems justified to consider the specific conflicts with the nomadic Masai. But even then the conflicts only reach a share of 17.4 percent. Food insecurity (10.4\%), health problems (7.6\%), supernatural phenomena $(4.3 \%)$, and environmental problems $(3.8 \%)$ were even more rarely mentioned. Food 
insecurity refers to the situation in which not everybody in the villages, at all times, has physical and economic access to sufficient, safe, and nutritious food (FAO, 2006).

The outstanding importance of theft among the fears of the interviewees becomes also obvious when adding up all the cases in which theft was named (see column "Total"). In fact, 57.3 percent of the respondents expressed fear of some type of theft. When the other two categories of crime are included, more than two-thirds $(68.2 \%)$ of respondents are afraid of some

Table 1: General future fears in rural Tanzania $(\mathrm{hh}$ - household)

\begin{tabular}{|c|c|c|c|c|}
\hline Type of fear & $\begin{array}{l}\text { Rank } 1 \\
(\% \text { hh })\end{array}$ & $\begin{array}{l}\text { Rank } 2 \\
(\% \mathrm{hh})\end{array}$ & $\begin{array}{l}\text { Rank } 3 \\
(\% \text { hh })\end{array}$ & $\begin{array}{l}\text { Total } \\
(\% \mathrm{hh})\end{array}$ \\
\hline Theft & 38.41 & 15.73 & 7.44 & 57.32 \\
\hline $\begin{array}{c}\text { Conflicts in } \\
\text { General }\end{array}$ & 10.00 & 12.93 & 10.49 & 30.85 \\
\hline $\begin{array}{l}\text { Food } \\
\quad \text { insecurity }\end{array}$ & 10.37 & 5.98 & 3.90 & 20.24 \\
\hline $\begin{array}{l}\text { Health } \\
\text { problems }\end{array}$ & 7.56 & 7.68 & 5.12 & 19.39 \\
\hline Supernatural & 4.27 & 6.46 & 2.56 & 12.80 \\
\hline $\begin{array}{c}\text { Environmental } \\
\text { problems }\end{array}$ & 3.78 & 5.24 & 2.93 & 11.71 \\
\hline $\begin{array}{c}\text { Conflicts with } \\
\text { Pastoralists }\end{array}$ & 7.44 & 1.46 & 0.37 & 9.27 \\
\hline Crime Other & 3.29 & 2.68 & 1.95 & 7.56 \\
\hline $\begin{array}{l}\text { Economic } \\
\text { problems }\end{array}$ & 2.20 & 1.83 & 2.68 & 6.22 \\
\hline $\begin{array}{l}\text { Social } \\
\text { problems }\end{array}$ & 1.59 & 2.44 & 2.32 & 6.22 \\
\hline $\begin{array}{l}\text { Drugs } \\
\text { addiction }\end{array}$ & 0.85 & 1.83 & 1.34 & 3.66 \\
\hline $\begin{array}{c}\text { Agricultural } \\
\text { problems }\end{array}$ & 0.49 & 1.71 & 2.20 & 3.54 \\
\hline Crime Killing & 1.46 & 1.71 & 0.12 & 3.29 \\
\hline Accidents & 1.10 & 1.34 & 0.85 & 3.17 \\
\hline
\end{tabular}

Note: $(\mathrm{n}=820)$. Numbers do not add up to $100 \%$ because of possible multiple responses. 
Table 2: Type and frequency of victimization (annual prevalence) $(n=378)$

\begin{tabular}{|c|c|c|c|c|c|}
\hline Type of crime & $\begin{array}{l}\text { Number of } \\
\text { affected } \\
\text { households } \\
\text { (n) }\end{array}$ & $\begin{array}{l}\text { Incidence } \\
\text { (mean) }\end{array}$ & $\begin{array}{l}\text { Severity } \\
\text { (mean) }\end{array}$ & $\begin{array}{l}\text { Damage } \\
\text { (in TZS) }\end{array}$ & $\begin{array}{l}\text { Reporting } \\
\text { (mean, } \\
1=\text { yes, } \\
0=\text { no) }\end{array}$ \\
\hline $\begin{array}{l}\text { Theft of agricultural products } \\
\text { / crops }\end{array}$ & 111 & 2.55 & 2.06 & 89,122 & 0.35 \\
\hline Theft of livestock / cattle & 85 & 1.79 & 1.99 & 49,424 & 0.44 \\
\hline $\begin{array}{l}\text { Crop / livestock vandalism } \\
\text { (destroying) }\end{array}$ & 65 & 1.86 & 2.49 & 197,765 & 0.55 \\
\hline Theft of personal property & 32 & 1.56 & 2.28 & 61,031 & 0.53 \\
\hline Theft of working tools & 19 & 1.39 & 2.06 & 86,083 & 0.21 \\
\hline Theft of bicycle & 10 & 1.1 & 2.4 & 83,500 & 0.6 \\
\hline $\begin{array}{l}\text { Robbery (to steal using } \\
\text { force/threaten) }\end{array}$ & 9 & 2.22 & 2.89 & $2,660,000$ & 0.78 \\
\hline Theft of firewood & 7 & 5.29 & 1.86 & 12,357 & 0 \\
\hline Assault/threat & 6 & 1.7 & 2.67 & 0 & 0.83 \\
\hline $\begin{array}{l}\text { Not returning borrowed } \\
\text { goods or money }\end{array}$ & 5 & 2 & 2 & 418,400 & 0 \\
\hline $\begin{array}{l}\text { Corruption in the health } \\
\text { care system }\end{array}$ & 5 & 5.2 & 1.8 & 35,000 & 0 \\
\hline $\begin{array}{l}\text { Consumer fraud (e.g. } \\
\text { cheating on quantity) }\end{array}$ & 4 & 2.25 & 2 & 4,250 & 0 \\
\hline $\begin{array}{l}\text { Burglary (enter home } \\
\text { [building] w/o permission) }\end{array}$ & 4 & 2 & 2.75 & 273,000 & 0.75 \\
\hline $\begin{array}{l}\text { Trader fraud (e.g. cheating on } \\
\text { quantity) }\end{array}$ & 3 & 1 & 2 & 71,666 & 0 \\
\hline $\begin{array}{l}\text { Theft from motorcycle } \\
\text { (radio, mirror) }\end{array}$ & 3 & 1.33 & 2.67 & 85,000 & 0.33 \\
\hline Theft of motorcycle & 3 & 2 & 3 & $2,690,000$ & 1 \\
\hline Attempted burglary & 3 & 1.33 & 2.33 & 58,333 & 0.67 \\
\hline Land robbery & 2 & 2 & 3 & 500,000 & 1 \\
\hline $\begin{array}{l}\text { Corruption in the } \\
\text { educational sector }\end{array}$ & 1 & 1 & 1 & 0 & 0 \\
\hline $\begin{array}{l}\text { Bribery / corruption (of } \\
\text { civil servants) }\end{array}$ & 1 & 1 & 1 & 20,000 & 0 \\
\hline
\end{tabular}

The severity ranges from "1: not serious" to "3: very serious". 
kind of crime. However, the corresponding proportions for conflicts $(30.8 \%$ or $9.3 \%)$ and food insecurity $(20.2 \%)$ are also not insignificant. For the latter, the question arises as to whether fears concerning the sufficient availability of foodstuffs could be related to thefts.

\section{Victimization experiences (annual prevalence)}

Against this background, the type and frequency of experiences with victimization are of great interest. The households were asked to respond to the following question: "Was your household affected by one of the following events in the last 12 months?" Victimizations were queried in a standardized manner. This was done in such a way that the 22 events (see Appendix A) were read out. If a victimization of one event had occurred in the last 12 months, questions about the frequency and severity of the incident followed (on a scale from "1 = not serious" to " 3 = very serious") along with questions about the damage done and reporting to authorities (Table 2). As a result, 300 households had become victims of a crime at least once in the 12 months preceding the survey. That equals 36.6 percent of the 820 households which provided answers. The affected households reported a total of 378 relevant incidents. They were victimized up to four times (multiple victimizations); the mean value was 1.26 incidents per household (Table 2).

Of the various offenses, theft played the most important role in the everyday reality of the rural population. However, violent injuries (assault, robbery), sexual delinquency, fraud and corruption hardly occurred. They made up only 7.7 percent (29 of 378) of all reported incidents. The fact that only seven cases of corruption were reported, most of them in the health care sector, is presumably due to the rural character of the survey region, where police officers, civil servants and government employees are absent, leading to few opportunities for corruption. The villages in which the surveys were conducted were between 4 and 40 kilometers from the nearest police station (average: $16 \mathrm{~km}$, median: $10 \mathrm{~km}$ ).

Tanzania is ranked 151th in the world, according to the Human Development Index, which takes into account the Gross National Income per capita, education, and life expectancy. Nearly half of the population (46.6 \%) disposes of less than US $\$ 1.90$ per day. ${ }^{2}$ Due to widespread poverty in its rural areas, the relevance of theft had been anticipated. Therefore, respective questions were differentiated, particularly with regard to items required for livelihood and being potential targets for theft (e.g., motorbike, bicycle, personal items, agricultural products, livestock, firewood, and working tools). In fact, seven out of ten reported incidents $(71.4 \% ; 270$ out of 378 incidents) were cases of theft. The most common cases were theft of agricultural or harvested products (111 cases) and the theft of cattle or other livestock ( 85 cases). If the seven attempted or completed cases of burglary are added, then the proportion of thefts in all reported incidents increases to 73.3 percent (277 of 378). Obviously, the mentioned fears of the rural population of theft are closely linked to their actual experiences. The feelings related to security of the respondents are severely impaired by actual cases of theft. 
In addition to the outstanding role of thefts, which decisively determine crime experiences and corresponding fears, there is another aspect that is linked to the agrarian character of the region. The overwhelming majority of all reported offenses were related to agriculture, on which their own income and the diets of their households depend. This applies to all thefts of agricultural products, livestock and working tools. This also includes vandalism with respect to field crops and animals, for which there are 65 cases. Together with the two cases of "land robbery", which is the unauthorized possession or use of land, 74.6 percent of the incidents (282 of 378) were agricultural in nature. In other words, over two-thirds of the incidents, namely 69 percent were the theft of agricultural products $(29.4 \%)$, cattle theft $(22.5 \%)$, or vandalism related to cattle or field crops $(17.2 \%)$. On the one hand, these property offences reflect the opportunities of theft in agricultural regions, but they also have serious consequences for those affected in areas where livelihoods depend on livestock and farming. Our results are in line with findings on the relevance of livestock theft in South Africa (Clack 2013) and Nigeria (Olowa, 2010) and crop theft in Ethiopia (Chiwona-Karltun et al., 2017).

Theft is therefore the most common offense in rural Tanzania. With regard to the 820 households surveyed, almost one-third of them were affected at least once, and generally suffered losses in farming assets. Referring only to the approximately 300 households who were victimized, just over half of those were victimized by theft. Like almost all offenses, these acts can be perpetrated at any time of the day. Nevertheless, there were some peculiarities which may be significant in the context of crime prevention. Thus, burglaries at the dwellings occurred exclusively in the afternoon or at night. Physical attacks or threats occurred - like theft or vandalism - at all times, but unlike the (few) attacks, the (many) property offenses clearly became more frequent from afternoon to dawn of the next day. Thus, 37 out of those 85 households affected reported that the theft of livestock had happened in the afternoon, while 25 households reported that the theft had occurred at night. For those 111 households victimized by theft of agricultural products, the theft was committed at night (50) or in the evening (35), and less often in the afternoon (23) or morning (2). Particularities also arose with regard to the crime location. Eighteen households were affected by livestock theft at their own homestead; agricultural products and field crops, however, were more frequently stolen from their fields (87) than from home (22).

On average, the households were victimized twice a year by a criminal offense (Table 2 , mean incidence values). In addition to the prevalence rates, this is also a sign of significant impacts of criminal acts on the rural population. Physical attacks or threats (1.2), thefts of bicycles (1.1) or parts of motorcycles (1.3), corruption with civil servants or officials or of the education system as well as fraud to the detriment of businesses (1.0) occurred significantly less often. In contrast, theft of firewood (5.3), corruption in the health care system (5.2), theft of agricultural products (2.6) and consumer fraud (2.3) were reported on average slightly more often than two times a year. Corruption in the health care or education system refers to situations in which somebody pays additional money for being treated or educated. 
Concerning the severity of the victimization (Table 2 , mean severity) - on a scale of "1: not severe" to "3: very severe" - respondents estimated cases of "land robbery" (3.00), robbery (2.89), completed burglary (2.75), physical attack or threat (2.67), as well as theft of motorcycle parts (2.67) as the most serious. Apart from the special case of "land robbery", these are acts of violence and theft of valuable things. It is interesting to note that while on the one hand theft of agricultural products and livestock, although or rather because it is quite common, is only assessed as "moderately severe". On the other hand, vandalism of field crops or livestock with a mean value of 2.49 falls somewhat out of the scope. The reasons for this need to remain open because questions about the theft of plants and animals were not asked separately. For this severity assessment, the "unfounded" attack on animals could be decisive. It is unlikely to be due to the animals' relevance for the food security situation of the owners and their households, since the theft of agricultural products, which can also endanger livelihood and food supply, is considered to be significantly less serious. Accordingly, the vandalism was also more frequently reported (Table 2, last column: 0.55$)$ than the theft of agricultural products and field crops $(0.35)$ or theft of livestock (0.44). The most frequently reported violations of the law (land robbery or theft, physical assault, robbery, burglary and theft of a motorcycle) were consequently reported as most serious.

\section{Reporting behavior, trust in institutions, feelings of security}

Reporting behavior was captured by asking: "To whom did you report the case?" Of the 378 cases (Table 3 ), only 162 were reported to others, while 216 cases remained unreported. Thus, in less than half of the cases $(42.9 \%)$ the affected households reported the incident somewhere. At the same time, reporting to the police played only a minor role. In fact, only 22 of all cases $(5.8 \%)$ were reported to the police. In 121 cases $(32 \%)$, the affected persons turned to the village chief or mayor or his or her representative. In only 143 cases, the offense was reported to an official authority (see Table 3 ). The cases submitted to village authorities accounted for 85 percent, while those reported to the police accounted for only 15 percent.

Table 3: Reporting behavior

\begin{tabular}{cccc}
\hline & Reported cases (n) & $\begin{array}{c}\text { Reported cases } \\
(\%)\end{array}$ & $\begin{array}{c}\text { Severity of case } \\
(\text { Mean }) *\end{array}$ \\
\hline Police & 22 & 15.38 & 2.64 \\
Village head & 121 & 84.62 & 2.43 \\
\hline$\left(\mathrm{n}=143^{3}\right), *$ Scale from " 1 = not severe" to "3 = very severe"
\end{tabular}

The data demonstrate the great importance of informal conflict resolution. Those 216 households which stated that they had not reported the case anywhere were asked how they 
had dealt with the problem. Of the 188 households which had answered the question, the majority believed that they had solved the problem "themselves" (114), "with the help of the village community" (16), or "by family/friends" (14). Twenty-three households said they had "done nothing". Households were also asked whether they had ever considered leaving their village because of the problems mentioned, but only 64 of the 820 households (8\%) answered "yes" to this question. In the majority of such cases, they had considered to move to a city (21) or the capital (12); 21 respondents had considered a move to another village.

The perceived likelihood for law enforcement authorities to deal with a case increased with the assessed severity. This is clearly shown by comparing the severity estimate (on a scale from "1= not serious" to "3 = very serious") of the reported 143 cases (mean: 2.46) with the 216 not reported cases (mean: 2.25). The same applies to the comparison of the means of the cases reported to the police (2.64) with the cases reported to the village head (2.43). As a result, the police is, if at all, only informed in cases considered to be particularly serious.

Households were then asked the question: "In case you did not report the case, why did you not report it?" We find that, in fact, 16.7 percent of those households who did not report said this was due to them not suffering much damage (Table 4). The vast majority of the respondents, 61.6 percent, however, considered a report simply futile and assumed it would not make any difference. For 6 percent of the interviewees, it was decisive that the nearest police officer was too far away; other victims (4\%) were able to settle the matter themselves.

Table 4: Reasons for not reporting $(n=216)$

\begin{tabular}{lcc}
\hline Reason & Cases not reported (n) & Percent \\
\hline does not help anything & 133 & 61.57 \\
damage was not big & 36 & 16.67 \\
distance to police station & 13 & 6.02 \\
solved it myself & 8 & 3.70 \\
perpetrator unknown & 5 & 2.32 \\
no time / too busy & 4 & 1.85 \\
no trust in police & 4 & 1.85 \\
afraid of reactions in & 4 & 1.85 \\
$\quad$ community & & \\
Others & 3 & 1.38 \\
missing & 5 & 2.32 \\
\hline
\end{tabular}

The trust in institutions, such as the Central Government, the local government, police, courts, religious and traditional institutions, Non Governmental Organizations (NGOs), the private sector and the village government, was captured by asking respondents the following four questions (Table 5): 
(i) "How strong is [institution]?" The possible responses ranged from " $1=$ very weak" up to $" 10=$ very strong" .

(ii) "How well does [institution] do its work? "The 10 point likert scale ranged from " $1=$ very ineffective" up to " $10=$ very effective".

(iii) "How much do you trust [institution]?” ("1 = not at all trustworthy" up to " $10=$ very trustworthy")

(iv) "How easy is it to get support without bribes from [institution]?" ("1 = very easy" up to "10 = very difficult")

It is possible that the very small number of cases (22 of 378) reported to the police is explained by the lack of trust in the police. Only a few households $(2 \%)$ explicitly stated this as a reason of non-reporting. However, respondents have relatively little confidence in the police (see Table 5: 6.47). Nevertheless, when asked how easy it is to receive help from them without paying a "bribe", respondents rated the police as second best while "traditional institutions" came first. In contrast, there is a relatively high level of trust in government authorities at state, local and village levels, and above all, in religious institutions.

The general feeling of security was assessed by asking whether or not the respondents themselves or members of their household felt insecure in their neighborhood at night. Results

Table 5: Trust in institutions (10 point Likert scale)

\begin{tabular}{|c|c|c|c|c|}
\hline & $\begin{array}{c}\text { Power of } \\
\text { [institution] }\end{array}$ & $\begin{array}{l}\text { Performance } \\
\text { of } \\
\text { [institution]* }\end{array}$ & $\begin{array}{c}\text { Trust in } \\
\text { [institution] }{ }^{* *}\end{array}$ & $\begin{array}{c}\text { Support } \\
\text { without bribes } \\
\text { from } \\
\text { [institution] }\end{array}$ \\
\hline Central government & 7.94 & 7.46 & 7.47 & 7.03 \\
\hline Local government & 7.22 & 6.91 & 6.90 & 6.60 \\
\hline Police & 7.14 & 6.50 & 6.47 & 5.94 \\
\hline Courts & 7.17 & 6.81 & 6.76 & 6.38 \\
\hline Religious institutions & 7.76 & 7.86 & 7.89 & 7.93 \\
\hline Traditional institutions & 5.01 & 5.07 & 5.04 & 5.12 \\
\hline NGOs & 6.60 & 6.66 & 6.63 & 6.72 \\
\hline Private Sector & 6.40 & 6.36 & 6.34 & 6.33 \\
\hline Village government & 7.18 & 6.98 & 6.88 & 6.74 \\
\hline
\end{tabular}


show a fairly pronounced sense of security because three-quarters of the interviewees had never felt unsafe in their neighborhood in the previous year. But how does this fit in with the fear of thefts reported at the beginning? Obviously, this anxiety is not mainly related to crime, which in fact does not seem to be threatening, apart from the high number of thefts. On the contrary, these concerns seem to be an expression of fear of widespread food insecurity. Theft of crops and farm animals is therefore perceived as a threat to one's own livelihood rather than problem of security in the village. With the present data, this hypothesis can be further substantiated. Respondents were referred to a number of potential social problems. On a scale from " $0=$ no fear" to " $5=$ very great fear", respondents were asked to indicate the extent of their concern that these problems might occur in their region. By comparing the mean values, it can be noted that poaching (3.32), illegal deforestation (3.40), alcoholism (3.44), loansharking (3.54) and gambling (3.54) created least worries. On the contrary, unemployment (3.59), illiteracy (3.64), drugs (3.67) and prostitution (3.74) were more feared. At the top of the fear values were counterfeit medicines (3.82), food insecurity (4.20) and land conflicts (4.24). Thus, thinking and acting of the interviewees obviously centers around personal food security.

\section{Prevention and severity assessment of offenses}

In view of the risks presented for the livelihood or personal property, respondents would be expected to make arrangements to avoid getting victimized. This is particularly true of anti-theft systems which are attributable to secondary criminal prevention. In fact, this is hardly the case, as

Table 6 shows. The precise question asked to the households was: "Have you made arrangements to protect yourself and your household from criminal offenses?"

Table 6: Safety measures

\begin{tabular}{lcc}
\hline & $\begin{array}{c}\text { Households } \\
(\mathrm{n})\end{array}$ & Percent \\
\hline did nothing & 466 & 56.83 \\
a guard & 1 & 0.12 \\
hiding & 5 & 0.61 \\
lighting & 3 & 0.37 \\
locks & 149 & 18.17 \\
neighborhood watch & 6 & 0.73 \\
not necessary & 13 & 1.59 \\
local informal police & 1 & 0.12 \\
help from god & 1 & 0.12 \\
self-defense with firearms & 5 & 0.61 \\
self-defense with knife / machete & 123 & 15.00 \\
a watchdog & 47 & 5.73 \\
\hline (n=820) & &
\end{tabular}


More than half of all households (57\%) do nothing to protect themselves against crime, in particular against theft. Less than one-fifth (18\%) use locks to prevent unauthorized intrusion or theft. And 15 percent of interviewees are prepared to defend themselves and their households in an emergency with a stab (knife, machete) or bat, while only about 6 percent have a watch dog. Hence, the rural population is doing little to protect themselves against crime. It must, of course, be kept in mind that they do not perceive crime - with the exception of numerous thefts - as threatening. In addition, preventive measures require financial resources that may not be available to everyone. Moreover, animals that are kept outdoors as well as seed or crops in the field are difficult to protect against attacks because the area may be large or too remote. Nevertheless, in view of these problems, only 64 of the households surveyed (8\%) have already thought about leaving their home village. Respondents then had considered 27 times a different village and 21 times a city with the capital being mentioned 12 times, and a foreign country only once.

The rating of severity of offenses was assessed using three fictitious case vignettes presented to the respondents (see Appendix A). For this purpose, one vignette each was made for bodily injury, theft, and insult - in order to examine how important the legal goods concerned were in terms of physical integrity, property, and honor. In the first case, two men are fighting and one of them broke the other person's nose (bodily injury). The second case describes the theft of the tools of a peasant who, as the perpetrator knows, can barely feed himself and his family (theft). In the third case, a young man insults his rival (insult). Vignettes allowed us to ask respondents about their opinions from the point of view of a concrete or realistic case, enriched with details. In this way, the vignettes attempt to tap into interviewees' differing ideas about a real-life crime, rather than a purely abstract offense.

Respondents were able to rate severity on a scale from "0: no offense" to "5: very serious offense". As a result, the interviewees considered theft for the most serious offense (scale 5: $60.3 \%$, scale $4: 23.4 \%$ ). In contrast, bodily injury was considered less serious (5: $52.4 \%$, 4: $23.1 \%)$. Insult was estimated to be the least serious (5: $43.2 \%, 4: 20.6 \%)$. Slightly over 6 percent $(6.2 \%)$ of the interviewees even said that this was not a criminal act at all, whereas in the other two cases, less than 1 percent of respondents shared this assessment.

The results can be understood as follows: unlike in industrialized countries, the infringement of property rights in agrarian societies with food insecurity is regarded as more serious than a violation of physical integrity. However, it must be considered that the described circumstances of the theft case (households' livelihoods are in danger, material enrichment as a motive) certainly contributed to the assessment of the interviewees. It may also have played a role that they may have identified themselves with the farmer in the case one vignette. Further research is needed to check whether there are differences in the severity of the offenses depending on the level of development. 


\section{Conclusion and discussion}

In rural Tanzania, theft is very common, and for many, it is one of the most unpleasant experiences to be experienced in the course of a year. These thefts mainly concern agricultural products and livestock, while serious crimes are rare. For the respondents, however, theft is not trivial, because to them there is a close link between fear of theft, theft experience and food security. In addition, respondents are particularly concerned about conflicts over land and the use of land. In this context, clashes with nomadic pastoral peoples play a central role, especially with Masai.

Our study confirms findings from Bunei et al. (2013) on the importance of farm crime in Africa. Especially, theft of crops and livestock are prevalent in Tanzania. However, our general victimization rates are lower, since the survey period refers to only 12 months while Bunei et al.'s study (2013) covered a period of five years. Moreover, our study focuses on small-scale producers without any employees. Bunei et al. (2013) stated that employed farm workers were partly responsible for the thefts.

Furthermore, the results of our victimization study can be linked from a victimology perspective to two studies, which were also conducted as household surveys. In the International Crime Victims Survey, the theft of personal property, burglary, theft of bicycles, motorcycles, and motor vehicles or parts thereof were considered. For Africa, the prevalence rate for theft over a period of five years was 13 percent, plus 8 percent for burglaries (Del Frate, 1998, p 29). In the German victimization survey, the annual prevalence rate (12 months) for thefts totaled 8.6 percent (Birkel, Guzy, Hummelsheim, Oberwittler \& Pritsch 2014, p 14) including personal theft, theft of the car, theft or attempted burglary, theft of a moped / motorbike / motorcycle and theft of a motor vehicle. In contrast, the annual prevalence rate for theft (including attempted and completed burglary) in rural Tanzania totaled 28 percent. The victimization rate is thus highest in our study. This is mainly due to the inclusion of theft of livestock, agricultural products, firewood and tools, which are typical of the rural context, and which were taken for the first time into account in such detail in this study. This expansion of theft is necessary in a country where a third of the population is undernourished according to the world hunger index (Deutsche Welthungerhilfe, 2015). It follows that in the questionnaire design, the victimization experiences need to be adapted to the life circumstances of the interviewees in order to better understand the actual victimization risks.

In rural areas, the high number of thefts is favored by the fact that safety precautions are rarely taken, and areas used for agricultural purposes and, in some cases, areas belonging to the residential area (for example, open kitchens) are easily accessible. These considerations lead to the theory of Routine Activity Approach, according to which, in addition to a motivated offender, the existence of a suitable target and the absence of a capable guardian (persons or security measures) are the causes of criminal offenses (Bunei \& Barasa, 2017, Ceccato, 2016, Grote \& 
Neubacher, 2016). In this context, the mere visibility and accessibility of an object play a role, because they are the ones which make a potential perpetrator aware of a crime opportunity. In any case, our results show that rural areas - as the emerging Rural Criminology (Donnermeyer \& DeKeseredy, 2014) emphasizes - should not be transfigured as an idyll that is spared by crime phenomena. On the contrary, it is justified to specifically identify rural crime with the term "farm crime", which is not solely but predominantly including theft. Finally, it is striking that the motives of not reporting a criminal offense are very similar in rural areas of a developing country to those in developed countries like Germany, and can be traced back to the low success prospects of prosecution or the low damage.

From a methodological point of view, our study is subject to a number of limitations. This is firstly the case for the differently strong willingness of respondents to talk about certain offenses. For this reason, it refrained from interrogating sexual or domestic violence. The people in Tanzania, especially in the countryside, can be described as rather "reserved". It was therefore all the more important that country representatives were used in the survey teams, which should have significantly increased respondents'willingness to participate. In addition, research could be based on an already existing trust base because the framework project in which the victimization study was embedded is a recurring survey of the rural population. At the same time, it cannot be completely ruled out that there was a bias in responses regarding different offenses because thefts were reported more willingly than physical violence.

Secondly, in the context of the (non-crime section) thematic food security survey, the participating households were potentially primed to these issues, so that they were more likely to be reminded of thefts related to food than to non-food-related criminal acts or that they considered these as particularly relevant to research.

Thirdly, a distortion by the interviewer (enumerator bias) must be taken into account. The interviewers were, to varying degrees, able to generate responses to the survey questions from the respondents. This also applies to victimization. While an interviewer recorded a criminal offense with 72 percent of the households, the interviewer with the lowest rate was 8 percent of the households (average of all interviewers: 38\%). Respondents were particularly cautious when it came to questions about the performance of regional or central government agencies; in addition, about a third of the interviewees had a problem in understanding the case vignettes.

Developing countries, as well as the rural peoples and communities, there are a new field of research for victimology. Our study shows that the collection of data is possible and valuable in this area, because specific problems can be touched, which could be characteristic of each country. In the near future, data from Kenya will be available, which will allow an inter-African comparison for the first time. In the future, links to gender and social inequality are also to be looked at more closely. In the long run, the use of qualitative methods also appears to be promising in order to investigate the presented problems with even greater depth of focus. 


\section{Endnotes}

${ }^{1}$ For comparison: Germany is in fourth place (source: Human Development Reports http://hdr.undp.org/en/data, last checked on 17.05.2017).

${ }^{2}$ On a global average, only $10.7 \%$ of the population (Source: World Bank, Poverty and Equity Data - http://povertydata.worldbank.org/poverty/home/, last reviewed on 17.05.2017).

${ }^{3} 19$ further people said they had reported to the elderly (2), the family (6), friends (9) and neighbors (2).

\section{Acknowledgement}

The authors wish to express their gratitude to the research teams from the universities of Hanover and Morogoro who conducted the interviews on site, in particular Kathleen Brüssow, Luitfred Kissoly and Gregor Mager.

\section{References}

Alvazzi Del Frate, A. (Ed.) (1998). Victims of crime in the developing world. Rome: UNICRI Publication No. 57.

Birkel, C., Guzy, N., Hummelsheim, D., Oberwittler, D. and Pritsch, J. (2014). Der Deutsche Viktimisierungssurvey 2012: Erste Ergebnisse zu Opfererfahrungen, Einstellungen gegenüber der Polizei und Kriminalitätsfurcht. Freiburg i. Br.: Max-Planck-Institut für ausländisches und internationales Strafrecht. Retrieved 22/06/2017 from https://www.mpicc.de/files/pdf3/a7_2014_Viktimisierungssurvey_2012.pdf.

Bunei, E.K., and F. Barasa. (2017). Farm crime victimisation in Kenya: A routine activity approach. International Journal of Rural Criminology, 3(2), 224-249. https://doi.org/10.18061/1811/81046

Bunei, E. K., J. K. Rono, and S. R. Chessa. (2013). Factors influencing farm crime in Kenya: opinions and experiences of farmers. International Journal of Rural Criminology, 2, 75100. https://doi.org/10.18061/1811/58846

Ceccato, V. (2016). Rural crime and community safety. Abingdon, Oxon: Routledge. https://doi.org/10.4324/9780203725689 
Chiwona-Karltun, L., M. Lemenih, M. Tolera, T. Berisso, and E. Karltun. (2017). Crop theft and soil fertility management in the highlands of Ethiopia. International Journal of Rural Criminology, 3(2), 176-190. https://doi.org/10.18061/1811/81048

Clack, W. J. (2013). The extent of stock theft in South Africa, Acta Criminologica: Southern African Journal of Criminology, 26(2), 77-91.

Deutsche Welthungerhilfe e. V. (2015). Welthungerindex. Hunger und bewaffnete Konflikte. Retrieved 22/06/2017 from http://www.welthungerhilfe.de/ueber-uns/mediathek/whhartikel/welthungerindex2015-pdf.html.

Donnermeyer, J. F. \& DeKeseredy, W. S. (2014). Rural criminology. Abingdon, Oxon: Routledge.

FAO (2006). Food Security. Policy Brief, June 2006, Issue 2. Food and Agriculture Organization, Rome. Retrieved 10/02/2018 from http://www.fao.org/forestry/13128-0e6f36f27e0091055bec28ebe830f46b3.pdf.

Graef, F., Sieber, S., Mutabazi, K., Asch, F., Biesalski, H. K., Bitegeko, J., Bokelmann, W., Bruentrup, M., Dietrich, O., Elly, N., Germer, J.U., Grote, U., Herrmann, L., Herrmann, R., Hoffmann H., Hahimba, F.C., Kaufmann, B. \& Uckert G. (2014). Framework for participatory food security research in rural food value chains. Global Food Security, 3, 8-15. https://doi.org/10.1016/j.gfs.2014.01.001

Grote, U. and Neubacher, F. (2016). Rural Crime in Developing Countries: Theoretical Framework, Empirical Findings, Research Needs. ZEF Working Papers No. 148. https://doi.org/10.2139/ssrn.2756542

Neubacher, F. and Grote, U. (2016). Rurale Kriminalität in Entwicklungsländern. Monatsschrift für Kriminologie und Strafrechtsreform, 99, 199-214. https://doi.org/10.1515/mkr-2016-0303

Olowa, O. W. (2010). The effect of livestock pilferage on household poverty in developing countries: Theoretical evidence from Nigeria. Bangladesh e-Journal of Sociology, 7(1), $42-46$.

van Dijk, J. (2008). The world of crime: breaking the silence on problems of crime, justice, and development across the world. Thousand Oaks, London: Sage Publications. https://doi.org/10.4135/9781483329789 
van Kesteren, J., J. van Dijk, and P. Mayhew (2014). The international crime victims surveys: a retrospective. International Review of Victimology, 20, 49-69. https://doi.org/10.1177/0269758013511742

Zvekic, U. \& Alvazzi Del Frate, A. (Eds.) (1995). Criminal victimisation in the developing world. Rome: UNICRI Publication No. 55.

\section{Appendix A: Fear Categories and Vignettes}

\section{Fear categories and the corresponding entries}

1. Supernatural: Superstition, god / sin, witchcraft, black magic, vampirism

2. Conflicts with nomads: Invasion or disruption of the herds through Masai, conflicts with Masai (nomadic people), land conflicts

3. Food insecurity: hunger, food security, uncertainty

4. Environmental problems: drought, earthquake, flood, climate, natural catastrophes

5. Health problems: old-age diseases, own death / death of relatives, own diseases / diseases of relatives, epidemics, far distance to / total lack of medical care

6. Accidents: Fire, hardness of life, accidents in traffic, encounter with / bite of wild animals, snake bites

7. Crime - killing: killing, killing, stabbing, slaughtering; Traffickers who kill; Murder to use parts of the corpse (related to albinos); killing and skinning; To beat to death

8. Crime - theft: theft of grain / livestock / by children / by strangers

9. Crime - Other: banditry, burglary, fake drugs, prison, violence, criminals, corruption, trafficking, bullying, robbery and prostitution, robbery with death, sexual violence, raid, rape

10. Conflicts in general: uprisings, insults, relationship with another man's wife, civil war, humiliation, jealousy, expropriation of the ground by government, ethnic conflicts, enmity, ignorance, conflicts with: peasants, family; Gossip, land conflicts and shortcomings, lies, political problems, private separation, tribal conflicts, disputes, uncertain property ownership of land, injustice, uncertainty 
11. Agricultural problems: hybrid seed, land shortage, plant pests, pesticide / fertilizer prices, salt water, fluctuations in grain prices, infertile soils, unsafe water supply, livestock diseases, far distance to water source

12. Drugs / addiction: alcoholism, drug addiction, gambling, smoking

13. Economic problems: unemployment, poverty, distance to source of firewood, lack of own ground, lack of storage space, lack of capital for business expansion, business building to purchase equipment or seed; Loans, loansharking, poor accommodation, debts, bad roads / transport problems, veterinarian, transport costs

14. Social problems / concerns: laziness, early marriage, not allowed to live in the husband's house, lack of education, organized youth groups, misbehavior of youth, prostitution, noise pollution

\section{Vignettes}

Case A: In a local club, two men (both 35 years old and not drunk) start fighting over a village gossip. One of them intentionally hits the other one hard into his face breaking his nose. As a result, the injured man cannot go to work for one week.

Case B: A 40-year old man steals farm tools from a small farm knowing that the farmer is a poor man who has not enough money to buy new tools and who does not know how to make a living for himself and his wife and his two small children. The offender wants to sell the tools on a nearby market in order to have money for new clothes.

Case $C$ : Two young men like the same woman. To ridicule his rival one man calls the other one a "lazy bum" and a "loser" while the young woman and her family are present. 